\title{
Identification of adverse reactions to new drugs. I: What have been the important adverse reactions since thalidomide?
}

\author{
GEOFFREY R VENNING
}

\begin{abstract}
A consensus process was used to establish an agreed list of important adverse reactions to drugs identified since thalidomide. Ten physicians working in medicine in Britain and 10 physicians responsible for drug regulatory agencies in different countries were asked to list 10 important adverse reactions to drugs since thalidomide. From these 20 lists a measure of agreement was apparent. Eighteen important adverse reactions were identified for further study of the discovery processes now operating and of the delays occurring from marketing to alerting, from alerting to verification, and from verification to regulatory action.

The results suggest that an empirical review of this type is necessary as a starting point for discussion of better systems to reduce delays in the discovery of adverse reactions to new drugs.
\end{abstract}

\section{Introduction}

Empiricism has been neglected in reviews of the identification of adverse drug reactions. Discussion of better systems for discovering adverse reactions to new drugs at an earlier stage has suffered from a shortage of factual data on several aspects of the problem. Logical analysis should include identification of the

University Department of Community Medicine and General Practice, Oxford

GEOFFREY R VENNING, BM, FRCP, visiting scientist (now director of research and development, Janssen Pharmaceutical Limited, Marlow, Bucks SL7 1ET) serious and important unwanted effects that have occurred, assessment of the discovery process of each of the main adverse effects, and study of the avoidable delays both in discovery and in regulatory action. I have therefore reviewed the present position from scratch to try to ascertain essential baseline data without which sensible proposals for change are unlikely to be made. In this and subsequent articles the problem is analysed as follows.

Part I-What have been the most important adverse reactions to drugs identified since thalidomide? A list of important reactions was generated by an informal process of consensus development.

Part II-Published work was reviewed to assess how 18 important reactions identified in part I were in fact discovered. The discovery process is analysed into alerting and verification mechanisms, and the time lags in the discovery process assessed from marketing to alerting, from alerting to verification, and from verification to regulatory action.

Part III-Using the data obtained in parts I and II, I have tried to evaluate the contribution of different skills, techniques, and monitoring processes to the discovery of adverse reactions and to assess the relative efficacy of different "early-warning systems" for first alerting.

Part IV-Also with data obtained in parts I and II, I have reviewed and evaluated the verification processes. An overall assessment is made of different approaches to the discovery of adverse drug reactions.

What have been the most important adverse drug reactions since thalidomide?

Many papers have been written on the problem of how to identify adverse reactions to drugs, but I know of no attempt to list the most important reactions. There are many different methods of identifica- 
tion and the proponents of each approach tend to review those adverse reactions that have been discovered in their own particular manner. Some epidemiologists are proponents of case-control studies, ${ }^{1}$ and others favour cohort observational studies ${ }^{2}$; clinical pharmacologists and physicians follow the experimental rather than the observational method when conducting large scale clinical trials; drug regulatory agencies publish the findings of specific national systems for reporting adverse reactions ${ }^{3}$-for example, the yellow card system in the United Kingdom ${ }^{4}$; and hospital drug surveillance programmes represent another approach to the problem. ${ }^{5} \mathrm{Lists}$ of adverse reactions from these groups of investigators differ, and it is not possible to compare and evaluate their suggestions for improving the system, since they are each addressing themselves to a different subset of the problem. The first step in any logical approach must therefore be to establish an agreed list of serious adverse reactions before trying to review what discovery processes are operating, with what delays, and with what scope for improvement.

The classification and analysis of study designs in these different approaches to the discovery of adverse reactions are examined in detail in parts III and IV. At this stage it should be noted that the main dichotomy is between, on the one hand, methods based on drug users-such as controlled and uncontrolled clinical trials and cohort studies, including various proposals for postmarketing surveillance by monitored or recorded release ${ }^{6-11}$-and, on the other hand, methods based on analysis of patients suffering particular illnesses or syndromes suspected of being drug induced. This second approach includes studies based on national statistics or disease registries, ${ }^{12}{ }^{13}$ hospital surveillance schemes, ${ }^{514-19}$ and case-control studies. ${ }^{1}$ The first class of design has the merit that the incidence of adverse reactions is known in relation to the denominator of drug users studied, and randomisation is possible. The second class has the merit that the prevalence of drug usage is known in relation to the denominator of patients suffering the particular suspected reaction, and adequate numbers of very rare events may be studied. National voluntary reporting systems ${ }^{3417}$ lack both types of denominator, quite apart from suffering the disadvantages inherent in underreporting. Other workers who have reviewed the various approaches to the discovery problem have also noted particular adverse reactions identified by the different methods. ${ }^{12-151819}$ Like those who have proposed the particular approaches to the problem, however, they have not addressed themselves to identifying the main reactions and to their discovery, and have often failed to distinguish clearly the problems of alerting from those of verification. These are evaluated in parts III and IV.

\section{Methods}

Ten physicians working in medicine in Britain and 10 professional heads of drug regulatory authorities were approached. Each was asked to provide a list of the 10 most important adverse drug reactions since thalidomide; they were not asked to place these in order of importance, and "importance" was not defined, either geographically or in terms of criteria such as severity or frequency. Physicians were told that they could identify more than one adverse reaction from a particular drug if considered appropriate. Both sets of respondents were selected in a non-random manner. The British physicians included three professors of medicine, five clinical pharmacologists, four physicians with a special interest in the monitoring of adverse reactions, and two experienced in epidemiology. Nine of the 10 regulatory agencies responded to the request: these represented Australia, Canada Holland, Italy, New Zealand, Sweden, United Kingdom, United States, and West Germany. The United States Food and Drug Administration sent separate responses from six different staff members, and a single composite consensus list was derived from these responses to avoid weighting the final list. To replace the nonresponder from one regulatory agency and so complete 10 lists from this source the principal medical officer of the adverse drug reactions section of the Medicines Division of the British Department of Health and Social Security (DHSS) kindly provided a list independent of that already obtained from the head of the division. The final outcome of the approach thus consisted of 20 independent lists, each containing 10 adverse reactions (apart from the composite American list, which contained 13 reactions).

In view of the subjective nature of the final list, with the possibility of recall bias leading to omission by the British physicians of important reactions for which effective regulatory action had occurred, objective validation was attempted. Data from the adverse reaction files of the DHSS were studied in an attempt to identify any major unwanted effect that might have been overlooked. Since the extent of under- reporting in any voluntary arrangement such as the British yellow card system is unknown it was decided to look at deaths rather than total adverse reactions: underreporting may be less for fatal adverse reactions, as the files include all death certificates in which a drug is mentioned as a contributory cause in addition to the deaths reported on yellow cards. There may, of course, be adverse reactions whose importance is in the resulting morbidity, even when mortality is minimal or absent; but review of deaths, though no more reliable than any review based on death certification, does at least provide an objective method of partial validation-positive findings providing information which cannot be ignored even though negative findings cannot be relied on.

\section{Results}

Tables I, II, and III give the frequency of identification of various adverse reactions as important, as shown by the number of physicians including each reaction in his list. Table $I$ also shows the extent of agreement between the British physicians and the regulatory authorities for the reactions listed most frequently.

TABLE I-Frequency of identification of adverse reactions included in list of 10 most important reactions since thalidomide

\begin{tabular}{|c|c|c|c|c|c|}
\hline & \multirow[b]{2}{*}{ Adverse reaction } & \multirow[b]{2}{*}{ Drug } & \multicolumn{3}{|c|}{ No of times included } \\
\hline & & & $\begin{array}{c}\text { By } 10 \\
\text { physicians } \\
\text { in UK }\end{array}$ & $\begin{array}{c}\text { By } 10 \\
\text { physicians } \\
\text { in regulatory } \\
\text { agencies* }\end{array}$ & Total \\
\hline (1) & Oculomucocutaneous & Practolol & 9 & 10 & 19 \\
\hline $\begin{array}{l}\text { (2) } \\
\text { (3) }\end{array}$ & $\begin{array}{l}\text { Thromboembolism } \\
\text { Nephropathy }\end{array}$ & $\begin{array}{l}\text { Oral contraceptive } \\
\text { Analgesics (es- } \\
\text { pecially } \\
\text { phenacetin) }\end{array}$ & $\begin{array}{l}10 \\
7 \dagger\end{array}$ & $\begin{array}{l}7 \\
5+\end{array}$ & $\begin{array}{l}17 \\
12+\end{array}$ \\
\hline $\begin{array}{l}(4) \\
(5)\end{array}$ & $\begin{array}{l}\text { Lactic acidosis } \\
\text { Deaths from asthma }\end{array}$ & $\begin{array}{l}\text { Phenformin } \\
\text { Sympathomimetic } \\
\text { aerosols }\end{array}$ & $\begin{array}{l}3 \\
6\end{array}$ & 8 & $\begin{array}{l}11 \\
10\end{array}$ \\
\hline (6) & $\begin{array}{l}\text { Subacute myelooptic } \\
\text { neuropathy }\end{array}$ & Clioquinol & 5 & 5 & 10 \\
\hline (7) & $\begin{array}{l}\text { Vaginal cancer (in } \\
\text { daughters) }\end{array}$ & $\begin{array}{l}\text { Stilboestrol } \\
\text { (maternal) }\end{array}$ & 4 & 5 & 9 \\
\hline $\begin{array}{l}(8) \\
(9) \\
(10)\end{array}$ & $\begin{array}{l}\text { Aplastic anaemia } \\
\text { Jaundice } \\
\text { Retroperitoneal } \\
\text { fibrosis }\end{array}$ & $\begin{array}{l}\text { Chloramphenicol } \\
\text { Halothane } \\
\text { Methysergide }\end{array}$ & $\begin{array}{l}1 \dagger \\
2 \\
3\end{array}$ & $\begin{array}{l}5 \dagger \\
4 \\
3\end{array}$ & $\begin{array}{l}6 \dagger \\
6 \\
6\end{array}$ \\
\hline $\begin{array}{l}(11 \mathrm{a}, \\
11 \mathrm{~b}) \\
(12) \\
(13)\end{array}$ & $\begin{array}{l}\text { Pseudomembranous } \\
\text { colitis } \\
\text { Aplastic anaemia } \\
\text { Dyskinesia (especially } \\
\text { tardive) }\end{array}$ & $\begin{array}{l}\text { Lincomycin, } \\
\text { clindamycin } \\
\text { Phenylbutazone } \\
\text { Phenothiazines }\end{array}$ & $\begin{array}{l}2 \\
2 \\
2\end{array}$ & $\begin{array}{l}4 \\
3 \\
3\end{array}$ & $\begin{array}{l}6 \\
5 \\
5\end{array}$ \\
\hline
\end{tabular}

* Australia, Canada, West Germany, Holland, Italy, New Zealand, Sweden, United Kingdom (2), United States (one composite list from six physicians).

$\uparrow$ These numbers may underestimate importance of reaction for reasons explained in text.

TABLE II-Reactions identified as important by two, three, or four physicians out of 20

\begin{tabular}{|c|c|c|}
\hline & Adverse reaction & Drug \\
\hline \multicolumn{3}{|c|}{ Identified as important by 4 physicians } \\
\hline $\begin{array}{l}(14) \\
(15)\end{array}$ & $\begin{array}{l}\text { Hepatic necrosis (overdosage) } \\
\text { Endometrial cancer }\end{array}$ & $\begin{array}{l}\text { Paracetamol } \\
\text { Postmenopausal oestrogens }\end{array}$ \\
\hline \multicolumn{3}{|c|}{ Identified as important by 3 physicians } \\
\hline$\left(16^{*}\right)$ & $\begin{array}{l}\text { Myocardial infarction } \\
\text { Sclersing peritonitis }\end{array}$ & Oral contraceptives \\
\hline $\begin{array}{l}\left(177^{*}\right) \\
(18)\end{array}$ & $\begin{array}{l}\text { Sclerosing peritonitis } \\
\text { Gastric bleeding }\end{array}$ & $\begin{array}{l}\text { Non-steroidal anti-inflammatory } \\
\text { agents (including aspirin, } \\
\text { indomethacin) }\end{array}$ \\
\hline (19) & Retinopathy. & Chloroquine \\
\hline (20) & Myocardial infarction & $\begin{array}{l}\text { Tolbutamide (etc) } \\
\text { Monoamine oxidase inhibitors }\end{array}$ \\
\hline$(22)$ & $\begin{array}{l}\text { Acute hypertension } \\
\text { Pulmonary hypertension }\end{array}$ & Aminorex fumarate \\
\hline (23) & Brain damage & Pertussis vaccine \\
\hline & Bone marrow toxicity & Pyrazolones \\
\hline \multicolumn{3}{|c|}{ Identified as important by 2 physicians } \\
\hline & Gall bladder disease & Clofibrate \\
\hline (26) & Breast cancer & $\begin{array}{l}\text { Reserpine } \\
\text { Anticonvulsants }\end{array}$ \\
\hline$(28)$ & $\begin{array}{l}\text { Fetal abnormalities } \\
\text { Osteomalacia }\end{array}$ & Anticonvulsants \\
\hline (29) & Osteoporosis & Corticosteroids \\
\hline (30) & Sudden death & $\begin{array}{c}\text { Amitriptyline (or tricyclic anti- } \\
\text { depressants) }\end{array}$ \\
\hline (31) & Deafness & Streptomycin \\
\hline
\end{tabular}

* Importance of reaction may be underestimated for reasons explained in text. 
TABLE III-Reactions identified by one physician only, out of 20

\begin{tabular}{|c|c|}
\hline Adverse reaction & Drug \\
\hline Liver toxicity & $\begin{array}{l}\text { Oxyphenisatin, isoniazid, glafenine, } \\
\text { erythromycin estolate }\end{array}$ \\
\hline Renal toxicity & Gentamicin, cephaloridine, tetracycline \\
\hline Allergy & Rifampicin \\
\hline Anaphylaxis & Rifampicin \\
\hline Anaphylaxis & Glafenine, dextran \\
\hline Drug abuse & Barbiturates, phenmetrazine \\
\hline Central nervous system sedation & Antihistamines, benzodiazepines (in elderly) \\
\hline $\begin{array}{l}\text { Central nervous system excitation } \\
\text { Convulsions }\end{array}$ & $\begin{array}{l}\text { Triazolam } \\
\text { Lithium }\end{array}$ \\
\hline $\begin{array}{l}\text { Convulsions } \\
\text { Neuropathy }\end{array}$ & Nitrofurantoin \\
\hline Encephalopathy & Hexachlorophane \\
\hline Deafness & Neomycin \\
\hline Cataract & Triparenol \\
\hline Agranulocytosis & Clozapine, aprindine \\
\hline Haemolysis & Brimaquine \\
\hline Methaemoglobinaemia & Phenacetin \\
\hline Lupus erythematosus & Venopyronum \\
\hline Gall stones & Oestrogens, oral contraceptives \\
\hline Bronchospasm & Propranolol \\
\hline Rebound hypertension & Clonidine \\
\hline Infection & Intravenous fluids \\
\hline Bioinequivalence & Digoxin \\
\hline Weight gain & Phenothiazines \\
\hline Sodium retention & Carbenoxolone \\
\hline Hyperglycaemia, hyperuricaemia & Thiazides \\
\hline Heart failure & Beta-blockers \\
\hline Dental toxicity & Tetracyclines \\
\hline Cancer & Azathioprine \\
\hline 2nd Cancer & Anticancer drugs \\
\hline Fetal abnormalities & Hormonal pregnancy tests \\
\hline
\end{tabular}

\section{Discussion}

There are many possible criteria of "importance" of adverse drug reactions, and I do not suggest that the list in table I is the only possible basis for reviewing the methods of discovery. An analysis of the discovery process for unwanted effects for all products withdrawn from the market would complement the present study. This approach was given a lower priority, however, for three main reasons. Firstly, drigs which have failed commercially are likely to be withdrawn voluntarily at an earlier stage in the assessment of an adverse reaction than are those that are successful. A list based on withdrawn drugs will therefore be biased towards reactions of less importance in respect of the numbers of users exposed to risk. Secondly, adverse reactions from uniquely useful drugs may not lead to withdrawal but may, nevertheless, be very important. This applies to reactions established as due to oral contraceptives, halothane, and aspirin and to reactions suspected of being associated with pertussis vaccine. Thirdly, "me-too" drugs which produce an adverse reaction are, on the other hand, more likely to be withdrawn promptly than drugs with important advantages.

Some comments are necessary on the strengths and weaknesses of the particular list identified based on the method by which it was developed. The decision to avoid precise definitions of adverse drug reactions and of criteria of importance was deliberate. Leaving this to the judgment of the physicians, who were unaware of the use to be made of the list, minimised bias towards or against adverse reactions which were discovered by any particular process. In this respect the list provides a better basis for a review of the discovery process than was available in previous reports on the problem. The method employed led to certain ambiguities in the responses. Although this resulted in underrepresentation of certain adverse reactions, this did not create a problem. Some physicians included keratoconjunctivitis and sclerosing peritonitis as separate effects of practolol, whereas others specified oculomucocutaneous syndrome or simply the practolol syndrome. When the latter response was given this was recorded arbitrarily as keratoconjunctivitis, as the eye damage was certainly the feature of the syndrome which caused most alarm to the public, the medical profession, and the regulatory agencies. Sclerosing peritonitis was included in three lists out of 20 , and this may be an underestimate of its importance in the minds of the responding physicians, some of whom included this problem in their general identification of this adverse reaction. The dermatitis component of the syndrome was not identified independently but was clearly important in terms of the discovery process. A similar situation arose in respect of the responses concerning thromboembolic disease with oral contraceptives. Some physicians specified myocardial infarction as a separate reaction; others expressed the view that this was merely part of the wider problem of "oral contraceptives and thrombosis." From the point of view of this study, however, the three components of the oculomucocutaneous syndrome with practolol were discovered independently, as were thromboembolism and myocardial infarction with oral contraceptives.

In reviewing the discovery mechanisms for these adverse reactions the processes whereby each component was first reported and later verified need to be identified; the reactions in table I are therefore regarded as totalling 16 rather than 13. With pseudomembranous colitis associated with lincomycin and clindamycin the responses also included an element of ambiguity. Some physicians specified one or other of these drugs, and others specified both drugs, which are closely related chemically and pharmacologically. Hence another problem arose. Pseudomembranous colitis was already known to occur occasionally with broad-spectrum antibiotics, particularly tetracyclines, but the reaction occurred with greater frequency in association with lincomycin and subsequently with clindamycin. The total is therefore expanded from 16 to 18 .

It is also necessary to identify how each of three adverse reactions was first reported and then verified-pseudomembranous colitis with broad-spectrum antibiotics, with lincomycin, and with clindamycin. Finally, in considering the lists it may be noted that the importance of two of the reactions may also have been underestimated in the minds of the responding physicians. Analgesic (phenacetin) nephropathy appeared in 12 lists out of 20 , despite the fact that some physicians excluded this as being a phenomenon of drug abuse rather than a true adverse reaction. The inquiry was not specific in this respect. Aplastic anaemia due to chloramphenicol appeared in six lists out of 20 , though some physicians may have considered, perhaps correctly, that this reaction preceded thalidomide. Despite these ambiguities both adverse reactions have found their way to the final list, and there do not appear to be any reactions omitted from table I as a result of underestimation consequent on the lack of detailed specification in the inquiry.

\section{Validation}

\section{NUMBERS OF DEATHS REPORTED}

Table IV shows the leading adverse reactions reported as causing death between 1964 and 1980 taken from the DHSS Medicines Division files, which include all yellow card reports plus death certificates in which a drug is mentioned. Table IV suffers from the defect that some adverse reactions reached a peak before the end of the period under review, and their importance may thus be underestimated-for example, deaths from asthma associated with sympathomimetic aerosols. Very few reactions omitted from the present study (as listed in table I) appeared prominently as causes of death, and most of the reactions included were major contributors to drug-associated deaths. The following comments are on the exceptions.

The importance of non-steroidal anti-inflammatory agents as causes of gastric bleeding may be overestimated in so far as some of these patients have ulcers that might give rise to fatal bleeding even without the drugs. The problem of aplastic anaemia was being studied in the context of phenylbutazone and chloramphenicol, so that the omission of gold from the survey may not be important. Anaphylaxis due to penicillin is an immediate adverse reaction occurring at the time of administration and poses no problem for discovery. Finally, 44 of the 149 deaths from analgesic nephropathy were associated with aspirin rather than phenacetin. So far as this study of discovery mechanisms is concerned, aspirin nephropathy, if real, may be regarded as a subset of analgesic nephropathy, and the story is still being unfolded. 
TABLE IV-Fatal reports 1964-80; yellow cards and death certificates

\begin{tabular}{|c|c|c|c|c|c|}
\hline & Adverse reaction & $\begin{array}{l}\text { Order in } \\
\text { tables I, II }\end{array}$ & Drug & No & Comment \\
\hline (1) & Aplastic anaemia & (12) & Phenylbutazone & 441 & Includes all blood \\
\hline (2) & Thromboembolism & (2) & $\begin{array}{l}\text { Oral contra- } \\
\text { ceptives }\end{array}$ & 404 & $\begin{array}{l}\text { dyscrasias } \\
\text { Pulmonary embo- } \\
\text { lism 268, } \\
\text { myocardial } \\
\text { infarct } 136\end{array}$ \\
\hline (3) & Gastric bleeding & (18) & $\begin{array}{l}\text { Non-steroidal } \\
\text { anti- } \\
\text { inflammatory }\end{array}$ & 326 & $\begin{array}{l}\text { Aspirin } 96, \\
\text { indomethacin } \\
83 \text {, phenyl- } \\
\text { butazone } 71 \text {, } \\
\text { other } 76\end{array}$ \\
\hline $\begin{array}{l}\text { (4) } \\
\text { (5) }\end{array}$ & $\begin{array}{l}\text { Hepatic necrosis } \\
\text { Nephropathy }\end{array}$ & $\begin{array}{l}\text { (9) } \\
\text { (3) }\end{array}$ & $\begin{array}{l}\text { Halothane } \\
\text { Analgesics } \\
\text { (especially }\end{array}$ & $\begin{array}{l}150 \\
149\end{array}$ & $\begin{array}{l}\text { Phenacetin } 105 \text {, } \\
\text { aspirin } 44\end{array}$ \\
\hline (6) & Deaths from asthma & (5) & $\begin{array}{l}\text { phenacetin) } \\
\text { Isoprenaline }\end{array}$ & 64 & \\
\hline (7) & $\begin{array}{l}\text { Pseudomembranous } \\
\text { colitis }\end{array}$ & (11) & $\begin{array}{l}\text { aerosols } \\
\text { Lincomycin, } \\
\text { clindamycin, etc }\end{array}$ & 53 & $\begin{array}{l}\text { Lincomycin 15, } \\
\text { clindamycin } 36, \\
\text { tetracyclines } 2\end{array}$ \\
\hline $\begin{array}{l}\text { (8) } \\
(9)\end{array}$ & $\begin{array}{l}\text { Lactic acidosis } \\
\text { Aplastic anaemia }\end{array}$ & $\begin{array}{l}(4) \\
(8)\end{array}$ & $\begin{array}{l}\text { Phenformin } \\
\text { Chloramphenicol }\end{array}$ & $\begin{array}{l}47 \\
42\end{array}$ & $\begin{array}{l}\text { Includes all blood } \\
\text { dyscrasias }\end{array}$ \\
\hline (10) & Aplastic anaemia & & Gold & 37 & $\begin{array}{l}\text { Includes all blood } \\
\text { dyscrasias }\end{array}$ \\
\hline (11) & $\begin{array}{l}\text { Oculomucocutaneous } \\
\text { syndrome }\end{array}$ & (1) & Practolol & 23 & $\begin{array}{l}\text { All sclerosing } \\
\text { peritonitis }\end{array}$ \\
\hline (12) & Anaphylaxis & & Penicillin & 23 & \\
\hline
\end{tabular}

Note: No deaths reported for clioquinol (subacute myelooptic neuropathy; No 6 in table I); stilboestrol (vaginal cancer; No 7 in table I); methysergide (retroperitoneal fibrosis; No 10 in table I); phenothiazines (tardive dyskinesia; No 13 in table I).

TABLE V-Important adverse reactions. Numbers of deaths 1975-9 and rate per million general-practitioner prescriptions for adverse reactions identified as important (see table I)

\begin{tabular}{|c|c|c|c|}
\hline Adverse reaction & Drug & $\begin{array}{c}\text { Rate per } \\
\text { million }\end{array}$ & No \\
\hline Pseudomembranous colitis & $\left\{\begin{array}{l}\text { Lincomycin } \\
\text { Clindamycin }\end{array}\right.$ & $\begin{array}{l}93 * \\
21^{*}\end{array}$ & $\begin{array}{l}13 \\
31\end{array}$ \\
\hline $\begin{array}{l}\text { Liver toxicity } \\
\text { Sclerosing peritonitis } \\
\text { Blood dyscrasia }\end{array}$ & $\begin{array}{l}\text { Isoniazid } \\
\text { Practolol } \\
\text { Phenylbutazone (includes } \\
\text { oxyphenbutazone) }\end{array}$ & $\begin{array}{l}20^{*} \\
16.9^{*} \\
7 \cdot 6\end{array}$ & $\begin{array}{r}10 \\
21 \\
125\end{array}$ \\
\hline Pulmonary embolism & Oral contraceptives & $4 \cdot 3$ & 217 \\
\hline $\begin{array}{l}\text { Gastric bleeding } \\
\text { Lactic acidosis } \\
\text { Nephropathy } \\
\text { Deaths from asthma }\end{array}$ & $\begin{array}{l}\text { Indomethacin } \\
\text { Phenformin } \\
\text { Phenacetin } \\
\text { Aerosols (isoprenaline) }\end{array}$ & $\begin{array}{l}2 \cdot 4 \\
2 \cdot 2 \\
1 \cdot 6^{*} \\
0 \cdot 5\end{array}$ & $\begin{array}{r}25 \\
30 \\
14 \\
3\end{array}$ \\
\hline
\end{tabular}

* Significant usage in hospital or over the counter means usage underestimated and rate overestimated.

Note: For halothane and chloramphenicol deaths were reported but problem of predominant hospital usage means calculation of rate not useful.

Maternal administration of stilboestrol was widespread in the United States at one time but not in Britain, and vaginal cancer as an adverse reaction has thus been mainly an American phenomenon. Subacute myelooptic neuropathy has been a Japanese phenomenon. This leaves two out of 14 adverse reactions which have occurred in Britain but not been associated with mortality. Retroperitoneal fibrosis after methysergide is a serious reaction, not usually fatal, arising from a drug used for migraine-a troublesome but seldom a serious disease. Retroperitoneal fibrosis is now recognised as a disease that other drugs may cause, so that its discovery after methysergide may, perhaps, have had seminal as well as intrinsic importance. Tardive dyskinesia after phenothiazines is another non-fatal reaction. It is important because it is a chronic and disabling condition which may persist for a long time or even indefinitely after the drug that caused it has been stopped.

Physicians responding to the questionnaire may not have recalled adverse reactions that were discovered promptly and resulted in early removal of a drug from the market. Numbers of deaths would not be an effective way of identifying such reactions; rates might, however, be better. The number of deaths reported was therefore noted in relation to the number of prescriptions. Unfortunately data were available only for general-practitioner prescribing and for the period 1975-9. Table $\mathrm{V}$ lists the reactions with the highest rates. For drugs widely used in hospital or available over the counter the extent of use is underrepresented by the denominator and the "rate" correspondingly overestimated. As with numbers of deaths, few adverse reactions not identified as important in this survey resulted in high rates of reporting of death. Hence studies of numbers of deaths and of rates of reporting of deaths per million general-practitioner prescriptions offer no particular reason to challenge the validity of the list developed in this survey, on the basis of either omission of important reactions or inclusion of relatively unimportant reactions. The list should therefore provide, for the first time, a reasonable data base for the purpose of objective assessment of how important adverse drug reactions have been discovered.

I thank the British physicians who completed the questionnaire (Sir Douglas Black; Professors A M Breckenridge, W I Cranston, D R Laurence, D H Lawson, and M P Vessey; and Drs D M Davies, A Herxheimer, R F Mahler, and L E Ramsay) and the physicians from the regulatory agencies (Drs J McEwen (Australia), I W D Henderson (Canada), and M N G Dukes (Holland); Professor D Poggiolini (Italy); Dr K H Goh (New Zealand); Professor A Liljestrand (Sweden); Drs J P Griffin and W H W Inman (UK); and Dr J K Jones (USA)). I also thank Dr J P Griffin for permission to publish data from the adverse reactions files of the DHSS.

The work was carried out in the department of community medicine and general practice, University of Oxford, while I was a senior medical officer in the Medicines Division of the DHSS.

Part II of this series will be published next week.

\section{References}

${ }^{1}$ Jick H, Vessey MP. Case control studies in the evaluation of drug induced illness. Am F Epidemiol 1978;107:1-7.

${ }^{2}$ Feinstein AR. Clinical biostatistics: the epidemiologic trohoc, the ablative risk ratio, and retrospective research. Clin Pharmacol Ther 1973;14: 291-307.

${ }^{3}$ Bottiger LE, Westerholm B. Drug-induced dyscrasias in Sweden. $\mathrm{Br} \mathrm{Med}$ F 1973;iii:339-43.

${ }^{4}$ Inman WHW, Price Evans DA. Evaluation of spontaneous reports of adverse reaction to drugs. $B r$ Med $\mathcal{F} 1972$;iii:746-9.

5 Jick H, Miettinen OS, Shapiro $\mathrm{S}$, et al. Comprehensive drug surveillance. ҰAMA 1970;213:1455-60.

6 Dollery CT, Rawlins MD. Monitoring adverse reactions to drugs. $\mathrm{Br}$ Med f $1977 ; \mathrm{i}: 96-7$

7 Inman WHW. Recorded release. In: Gross FM, Inman WHW, eds. Drug monitoring. London: Academic Press, 1977.

${ }^{8}$ Lawson DH, Henry DA. Monitoring adverse reactions to drugs: "restricted release" or "monitored release"? Br Med f 1977;i:691-2.

9 Wilson AB. Post-marketing surveillance of adverse reactions to new medicines. Br Med F 1977; ii:1001-3.

10 Walden RJ, Prichard BNC. Post-marketing drug surveillance. $\mathrm{Br} \mathfrak{F}$ Clin Pharmacol 1978;6:191-2.

11 Committee on the Safety of Medicines. Proposals for improved postmarketing surveillance. Pharmaceutical fournal 1978;220:193.

12 Doll R. Recognition of unwanted drug effects. Br Med F 1969;ii:69-76.

13 Doll R. Unwanted effects of drugs. Br Med Bull 1971 ;27:25-31.

14 Crooks J. The detection of adverse drug reactions. $\mathcal{F} R$ Coll Physicians Lond 1977;11:239-46.

15 Lawson DH. Monitoring for adverse drug effects. Pharmaceutical fournal 1978;220:201,204.

${ }^{16}$ Miller RR. Hospital admissions due to adverse drug reactions. Arch Intern Med 1974;134:219-23.

17 Esch AF. Food and Drug Administration drug experience reporting system. Fournal of Chemical Documentation 1969;9:66-70.

18 Bulpitt CJ. Screening for adverse drug reactions. Br F Hosp Med 1977;18 329-31.

19 Inman WHW, Vessey MP. Monitoring adverse drug reactions. In Bennett $\mathrm{AE}$, ed. Recent advances in community medicine. Edinburgh: Churchill Livingstone, 1978.

(Accepted 11 November 1982) 